University of Rhode Island

DigitalCommons@URI

$4-14-2014$

\title{
Uplift and Subsidence Reveal a Nonpersistent Megathrust Rupture Boundary (Sitkinak Island, Alaska)
}

\author{
Richard W. Briggs \\ Simon E. Engelhart \\ University of Rhode Island, engelhart@mail.uri.edu \\ Alan R. Nelson \\ Tina Dura \\ Andrew C. Kemp
}

See next page for additional authors

Follow this and additional works at: https://digitalcommons.uri.edu/geo_facpubs

\section{Citation/Publisher Attribution}

Briggs, R.W.; Engelhart, S.E.; Nelson, A.R.; Dura, T.; Kemp, A.C.; Haeussler, P.J.; Corbett, D.R.; Angster, S.J.; Bradley, L.-A. (2014). "Uplift and subsidence reveal a nonpersistent megathrust rupture boundary (Sitkinak Island, Alaska)." Geophysical Research Letters. 41(7): 2289-96. Available at: http://dx.doi.org/10.1002/ 2014GL059380

This Article is brought to you for free and open access by the Geosciences at DigitalCommons@URI. It has been accepted for inclusion in Geosciences Faculty Publications by an authorized administrator of DigitalCommons@URI. For more information, please contact digitalcommons-group@uri.edu. 


\section{Authors}

Richard W. Briggs, Simon E. Engelhart, Alan R. Nelson, Tina Dura, Andrew C. Kemp, Peter J. Haeussler, D. Reide Corbett, Stephen J. Angster, and Lee-Ann Bradley 


\section{Geophysical Research Letters}

\section{RESEARCH LETTER}

10.1002/2014GL059380

\section{Key Points:}

- Mixed coseismic uplift and subsidence at edge of 1964 M 9.2 rupture since $\sim 1$ ka

- First geologic evidence of the great

1788 earthquake and tsunami

- Non-persistent barrier to rupture

important for tectonic and

hazard models

Supporting Information:

- Readme

- Figures S1-S3 and Tables S1-S5

Correspondence to:

R. W. Briggs,

rbriggs@usgs.gov

\section{Citation:}

Briggs, R. W., S. E. Engelhart, A. R. Nelson, T. Dura, A. C. Kemp, P. J. Haeussler, D. R. Corbett, S. J. Angster, and L.-A. Bradley (2014), Uplift and subsidence reveal a nonpersistent megathrust rupture boundary (Sitkinak Island, Alaska), Geophys. Res. Lett., 41, 2289-2296, doi:10.1002/2014GL059380.

Received 22 JAN 2014 Accepted 2 MAR 2014

Accepted article online 26 MAR 2014 Published online 14 APR 2014

\section{Uplift and subsidence reveal a nonpersistent megathrust rupture boundary (Sitkinak Island, Alaska)}

\author{
Richard W. Briggs' ${ }^{1}$, Simon E. Engelhart ${ }^{2}$, Alan R. Nelson ${ }^{1}$, Tina Dura ${ }^{3}$, Andrew C. Kemp ${ }^{4}$, \\ Peter J. Haeussler ${ }^{5}$, D. Reide Corbett ${ }^{6}$, Stephen J. Angster ${ }^{1}$, and Lee-Ann Bradley ${ }^{1}$
}

${ }^{1}$ Geologic Hazards Science Center, U.S. Geological Survey, Golden, Colorado, USA, ${ }^{2}$ Department of Geosciences, University of Rhode Island, Kingston, Rhode Island, USA, ${ }^{3}$ Department of Earth and Environmental Science, University of Pennsylvania, Philadelphia, Pennsylvania, USA, ${ }^{4}$ Department of Earth and Ocean Sciences, Tufts University, Medford, Massachusetts, USA, ${ }^{5}$ Alaska Science Center, U.S. Geological Survey, Anchorage, Alaska, USA, ${ }^{6}$ Department of Geological Sciences, East Carolina University, Greenville, North Carolina, USA

Abstract We report stratigraphic evidence of land-level change and tsunami inundation along the Alaska-Aleutian megathrust during prehistoric and historical earthquakes west of Kodiak Island. On Sitkinak Island, cores and tidal outcrops fringing a lagoon reveal five sharp lithologic contacts that record coseismic land-level change. Radiocarbon dates, ${ }^{137}$ Cs profiles, computerized tomography scans, and microfossil assemblages are consistent with rapid uplift circa 290-0, 520-300, and 1050-790 cal yr B.P. and subsidence in A.D. 1964 and circa $640-510$ cal yr B.P. Radiocarbon, ${ }^{137} \mathrm{Cs}$, and ${ }^{210} \mathrm{~Pb}$ ages bracketing a sand bed traced $1.5 \mathrm{~km}$ inland and evidence for sudden uplift are consistent with Russian accounts of an earthquake and tsunami in A.D. 1788. The mixed uplift and subsidence record suggests that Sitkinak Island sits above a nonpersistent boundary near the southwestern limit of the A.D. $1964 M_{w} 9.2$ megathrust rupture.

\section{Introduction}

The Alaska-Aleutian megathrust (Figure 1) has been the source of three earthquakes larger than $M 8.6$ since 1957 , yet the rupture and tsunami history of the subduction zone is largely unknown. The megathrust's paleoseismic history has been inferred from coastal and archaeological stratigraphy but only from Kodiak Island eastward (Figure 1) [Gilpin, 1995; Carver and Plafker, 2008; Hutchinson and Crowell, 2007; Shennan et al., 2008, 2014]. No previous paleoseismic or paleotsunami data along the Aleutian-Alaska megathrust are available west of central Kodiak Island, along a source region where tsunami modeling suggests large ruptures would have severe local impacts and could cause significant damage along the west coast of North America and Hawaii [Ryan et al., 2012; Ross et al., 2013].

The spatial and temporal behavior of megathrust rupture boundaries is important for theoretical models of earthquake occurrence and hazard analyses, but few paleoseismic observations exist to test rupture boundary histories over multiple earthquake cycles. The boundary between the A.D. $1964 M_{w} 9.2$ and the A.D. $1938 M_{w} 8.2$ ruptures [Johnson and Satake, 1994] (Figure 1) is assumed to represent a long-lived rupture barrier [Wesson et al., 2007], possibly related to the subducted Patton-Murray seamount chain and the Aja Fracture Zone [von Huene et al., 2012]. Rupture boundaries lasting several earthquake cycles have been recognized in Sumatra [Meltzner et al., 2012] and Chile [Melnick et al., 2009]. By contrast, megathrust ruptures have crossed fundamental structural barriers such as a plate triple junction in the Solomon Islands [Taylor et al., 2008]. Previous studies in Alaska suggested that the Alaska-Aleutian megathrust and the Yakutat microplate ruptured together in prehistoric times beyond the eastern edge of the A.D. 1964 rupture [Shennan et al., 2009] and that segments within the A.D. 1964 rupture zone combine in variable patterns [Hutchinson and Crowell, 2007; Shennan et al., 2014].

To test the persistence of the western boundary of the A.D. 1964 rupture, we investigated the paleoseismic history of the southern coast of Sitkinak Island, $15 \mathrm{~km}$ southwest of Kodiak Island (Figure 1). Because it is located $\sim 120 \mathrm{~km}$ from the Alaska-Aleutian trench and above the subduction interface, the coastline of Sitkinak Island is expected to record sudden vertical motions associated with megathrust rupture. The amount and direction (uplift or subsidence) of coseismic land-level change is dependent on site location with 

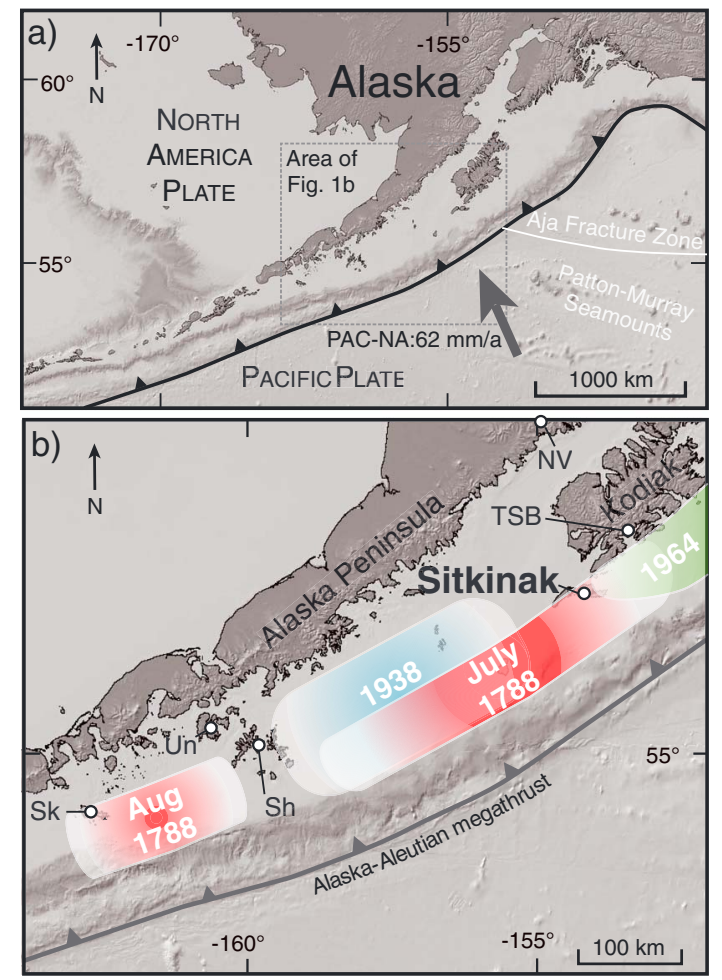

Figure 1. Location map. (a) Plate boundary context [Ryan et al., 2009; Argus et al., 2010; Matthews et al., 2011]. (b) Location of Sitkinak Island with respect to previous megathrust ruptures (modified from Johnson and Satake [1994], Lander [1996], and Carver and Plafker [2008]). Surface uplift region only of the 1964 rupture depicted, from Plafker and Kachadoorian [1966]. TSB: Three Saints Bay, Sh: Shumagin Islands, Un: Unga Island, Sk: Sanak Island, NV: Novarupta. respect to megathrust slip patches [Savage and Hastie, 1966] and is manifest in coastal sediment as an abrupt change in relative sea level [Plafker and Savage, 1970; Atwater, 1987]. Coseismic uplift on the northern coast of Sitkinak Island in A.D. 1964 was estimated at $0.45 \pm 0.3 \mathrm{~m}$ [Plafker and Kachadoorian, 1966] with no significant tsunami [Britt, 1965; Plafker, 1969], consistent with the island marking the endpoint of significant megathrust slip in A.D. 1964. Sitkinak Island sits above a highly coupled ( $>90 \%$ ) portion of the megathrust and is currently undergoing interseismic subsidence at $\sim 7 \mathrm{~mm} / \mathrm{yr}$ (data available at http://pbo.unavco.org/ station/data/AC45/). High coupling (>70-90\%) extends at least $380 \mathrm{~km}$ southwest of Sitkinak Island to near the Shumagin Islands where GPS observations suggest the interface is primarily creeping [Fournier and Freymueller, 2007; Freymueller et al., 2008].

We describe lithostratigraphic and microfossil evidence of five sudden land-level changes-both uplift and subsidence-and seawater inundation of freshwater marshes in the southwestern part of Sitkinak Lagoon. We present evidence of sudden uplift and a sand sheet from the fifteenth to nineteenth centuries on Sitkinak that we infer record a large megathrust rupture in A.D. 1788 and the tsunami it generated. We outline observations that suggest multiple tsunamis after circa $2.2 \mathrm{ka}$ and prior to A.D. 1788 are recorded on the southern coast of Sitkinak. Finally, we discuss evidence that megathrust ruptures do not always stop at Sitkinak as was observed in A.D. 1964 and the implications of our observations for seismic hazard models.

\section{Methods}

We examined deposits in the southwestern arm of the Sitkinak Lagoon (Figure 2) for evidence of sudden land-level changes and tsunami inundation. Sediment samples were obtained and described from 15 hand-driven cores and five tidal bank exposures along three transects. We used foraminiferal and diatom assemblages to infer the direction, but not magnitude, of sudden land-level changes (Tables S1 and S2 in the supporting information). Computerized tomography scans show unit density contrasts and reveal contact sharpness and continuity that is not always clear from optical inspection (Figures 3, S2, and S3 in the supporting information). ${ }^{137} \mathrm{Cs},{ }^{210} \mathrm{~Pb}$, pumice identification (by major oxide glass geochemistry), and accelerator mass spectrometry (AMS) ${ }^{14} \mathrm{C}$ methods date possible tsunamis and land-level changes (Tables S3-S5). We established vertical elevation control by calculating local orthometric heights with a real-time kinematic Global Positioning System (GPS) survey.

\section{Evidence for Coseismic Uplift and Subsidence}

Tidal and wetland deposits along the edge of the lagoon consist primarily of alternating peat and silt (Transect 3, Figures 2 and S1). To test whether abrupt lithologic transitions represent sudden land-level changes or normal variability in tidal sedimentation due to storm-induced or regional sea-level changes, we considered the criteria that Nelson et al. [1996] and Hemphill-Haley [1995] used to infer sudden coseismic land-level change in tidal settings: (i) the suddenness of vertical change, (ii) the coincidence of land-level 


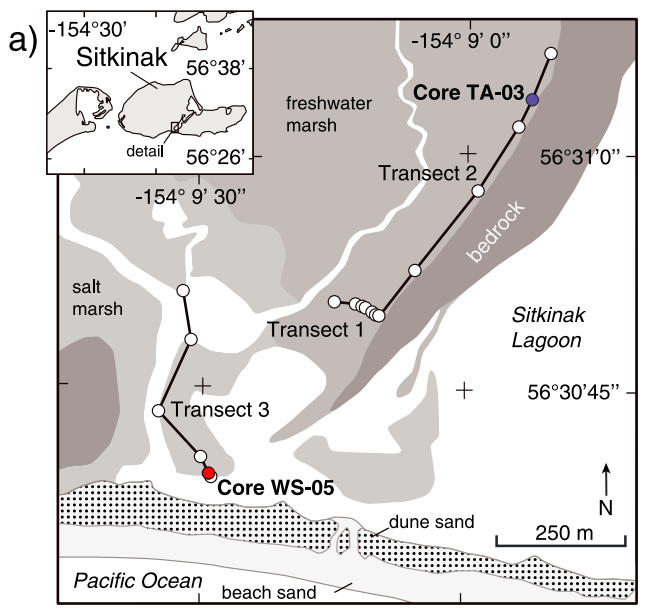

c) Transect 2

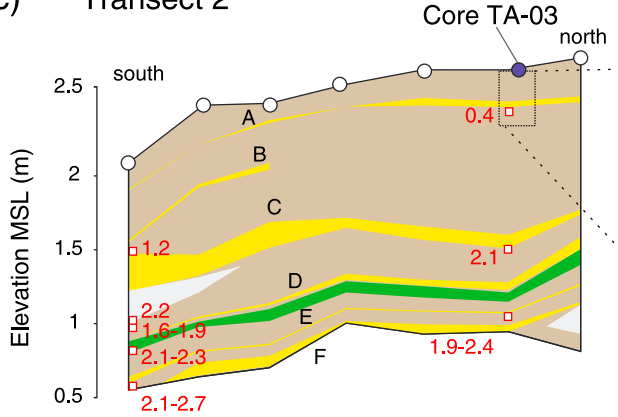

b) Transect 3

$$
\begin{array}{ll}
\square \text { silt dominated } & \text { abrupt sea-level fall } \\
\square \text { peat dominated } & \text { (uplift inferred) } \\
\square \text { sand bed } & \text { abrupt sea-level rise } \\
\text { (subsidence inferred) } \\
\square \text { pumice or tephra }
\end{array}
$$

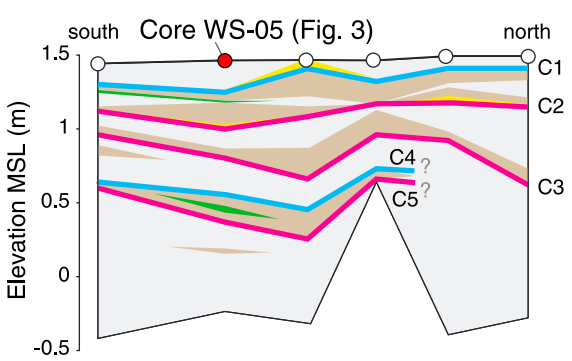

d)

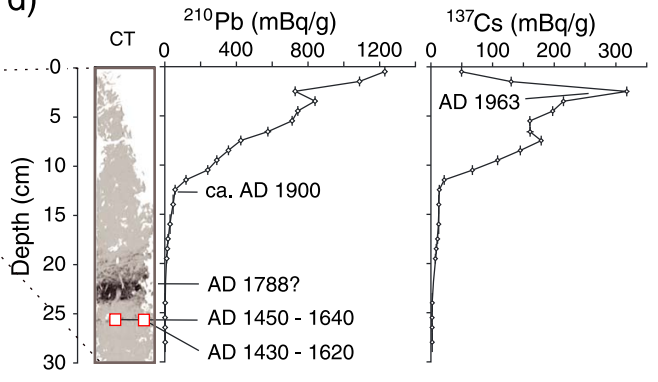

Figure 2. (a) Southern Sitkinak Lagoon site map showing generalized map units, core and exposure Transects 1-3, and core locations (open circles). (b) Core and exposure Transect 3 showing uplift and subsidence contacts C1-C5. (c) Core Transect 2 showing sand layers A-F and radiocarbon ages. Detail of the uppermost portion of core TA-03 containing sand layer A shows a computerized tomography scan (darker= denser), ${ }^{137} \mathrm{Cs}$ and ${ }^{210} \mathrm{~Pb}$ activity depth profiles, and $\mathrm{AMS}{ }^{14} \mathrm{C}$ dates.

change with tsunami deposits, (iii) the lateral extent of submerged or uplifted surfaces, (iv) changes in the composition of diatom and foraminiferal assemblages across sharp peat/silt and silt/peat boundaries, and (v) lasting change. Using these criteria, five contacts in core WS-05 (C1-C5; Figures 2, 3, and S2) that correlate along Transect 3 show evidence consistent with sudden land-level change. Two contacts (C1 and C4) mark sudden relative sea-level rise (coseismic subsidence), whereas three others $(C 2, C 3$, and $C 5)$ are consistent with abrupt relative sea-level fall (coseismic uplift) (Figures 2, 3, and S2).

Evidence for the most recent episode of sudden land-level change is a sharp, silt-over-peat contact (contact $\mathrm{C} 1$, Figures $2 \mathrm{~b}$ and 3 ) at $22 \mathrm{~cm}$ depth in core WS-05. A shift from a fresh-brackish, high-marsh diatom assemblage in the peat dominated by Navicula pusilla, Navicula peregrina, and Diploneis ovalis to a mixed lowmarsh/tidal flat assemblage containing Actinocyclus normanii, Actinoptychus senarius, and Synedra fasciculata in the silt implies a sudden rise in relative sea level, consistent with tectonic subsidence (Figure 3 and Table S2). Foraminifers above contact $\mathrm{C} 1$ consist of a mixed assemblage of high-marsh, low-marsh, and tidal flat species while foraminifers below the contact consist almost entirely of Balticammina pseudomacrescens, a common foraminifer found in the high salt marsh on Sitkinak [Kemp et al., 2013] suggesting that the peat formed near the highest reach of daily tides prior to sudden subsidence. Contact $\mathrm{C} 1$ is covered by a thin sandy layer in nearby core WS-03, but we could not find a correlative sand layer in higher cores inland. Maximum ${ }^{137} \mathrm{Cs}$ activity straddles contact $\mathrm{C} 1$ at $21-23 \mathrm{~cm}$ depth and records the peak of atmospheric flux associated with nuclear testing in 1963, dating the subsidence to A.D. 1954-1964 (Figure 3 and Table S3). Novarupta-Katmai pumice at $28 \mathrm{~cm}$ depth, erupted in A.D. 1912 and possibly rafted into the site [Fierstein and Hildreth, 1992], provides a maximum age for contact C1 (Table S4). The lithologic, microfossil, and geochronologic evidence is consistent with subsidence of the south coast of Sitkinak Island during the A.D. 1964 rupture, accompanied by little or no tsunami inundation as reported by Britt [1965] and Plafker [1969]. 


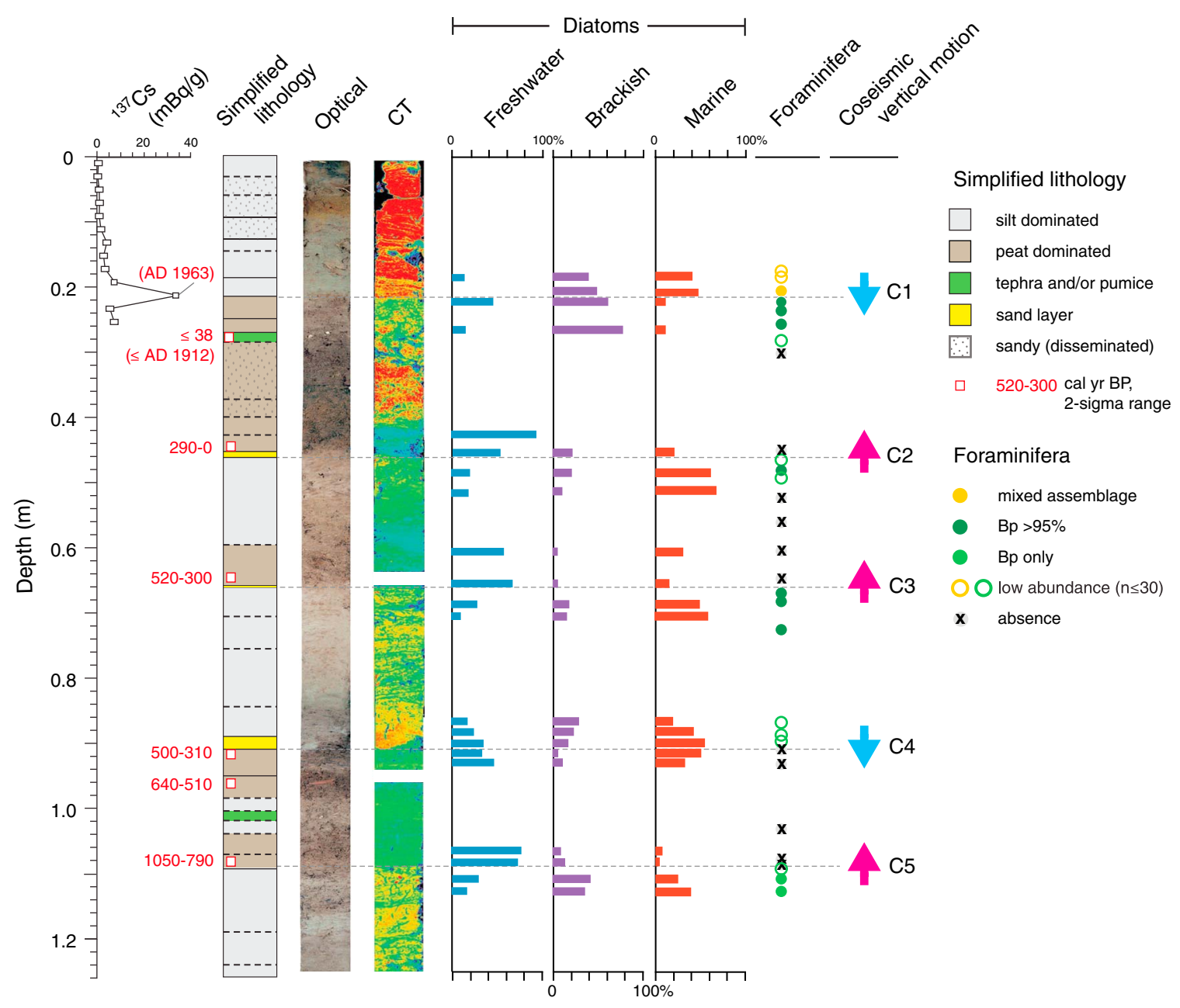

Figure 3. Core WS-05 showing (from left to right) ${ }^{137}$ Cs activity depth profile, age (cal yr B.P.), simplified lithology (dashed lines are gradational ( $<3 \mathrm{~mm}$ ) contacts), optical image, computerized tomography scan (red and orange = denser; blue and green = less dense; white = material removed prior to scanning), diatom assemblages as percentages of total, foraminiferal assemblages (Bp: Balticammina pseudomacrescens), and direction of inferred coseismic land-level change across contacts $\mathrm{C} 1-\mathrm{C} 5$.

Sudden subsidence is also recorded at $91 \mathrm{~cm}$ depth in core WS-05 (Figure 3), where sandy silt and pebbles cap peat along the sharp irregular contact C4 (Figure S2). The presence of the tychoplanktonic marine taxa, Hyalodiscus scoticus, in the sediments directly above contact C4 supports the interpretation of a marine incursion (Figure 3 and Table S2). Foraminiferal assemblages, in particular the sudden appearance of B. pseudomacrescens, imply an abrupt change from a freshwater to saltwater environment. Because contact C4 is laterally extensive along tidal banks and the lithostratigraphy and microfossil data are similar to subsidence recorded across contact C1 (Figure 3 and Tables S1 and S2), we interpret the bulk of evidence as consistent with subsidence similar to that in A.D. 1964. AMS ${ }^{14} \mathrm{C}$ ages from peat below contact $\mathrm{C} 4$ suggest this sudden subsidence occurred after 640-510 cal yr B.P.

In contrast to subsidence recorded along contacts $\mathrm{C} 1$ and $\mathrm{C} 4$, we infer abrupt uplift where peat caps silt along sharp contacts at C2, C3, and C5 (Figure 3). At contact C2 at $46 \mathrm{~cm}$ depth, an abrupt transition from a silt with a diatom assemblage dominated by tidal flat species including Cocconeis scutellum, Paralia sulcata, and S. fasciculata to an overlying peat with a freshwater marsh assemblage dominated by the salt-intolerant benthic diatoms Pinnularia lagerstedtii and Eunotia lunaris is consistent with a sudden fall in relative sea level. The absence of foraminifer $B$. pseudomacrescens above contact $C 2$ also implies a sudden transition from marine to freshwater conditions. A $1 \mathrm{~cm}$ sandy layer separates the peat and silt in core WS-05 and contains a mix of fresh, brackish, and marine diatoms, which is a common characteristic of tsunami deposits [Hemphill-Haley, 1995]. An AMS ${ }^{14} \mathrm{C}$ age from seeds of the wetland sedge Scirpus spp. found in the peat layer 
date the uplift to the seventeenth century or younger (Table S5). In section 4, we explore the possibility that this uplift event and sand layer deposition occurred in A.D. 1788 and correlates with an extensive sandy bed of similar age farther inland.

Lithologic and microfossil contrasts across contacts C3 $(66 \mathrm{~cm})$ and C5 $(110 \mathrm{~cm})$ in core WS-05 record uplift similar to that observed across contact C2 (Figures 3 and S2). The epipelic tidal flat diatom C. scutellum (contact C3) and C. scutellum and N. peregrina (contact C5) dominate the silty mud below each contact. The peats overlying contacts $\mathrm{C} 3$ and $\mathrm{C} 5$ contain an abundance of freshwater marsh taxa including $E$. lunaris, P. lagerstedtii, Pinnularia subcapitata, and Pinnularia ignobilis, implying a sudden fall in relative sea level. A thin $(<1 \mathrm{~mm}$ ) very fine grained sand in a second core from the same site separates the silt from the peat above contact $\mathrm{C} 3$, consistent with tsunami inundation at the time of uplift. AMS ${ }^{14} \mathrm{C}$ ages from the peat just above contacts C3 and C5 suggest uplift occurred prior to 520-300 and 1050-790 cal yr B.P., respectively.

\section{Evidence for the Late Fifteenth-Nineteenth Centuries (A.D. 1788?) and Earlier Tsunamis}

A shallow, nearly continuous sand layer extends up to $1.5 \mathrm{~km}$ inland along Transects 2 and 3 (layer A; Figures 2

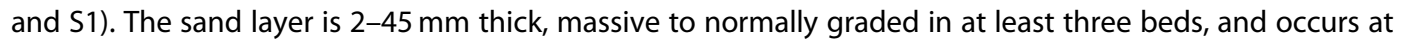
$12-45 \mathrm{~cm}$ depth (Figures S1 and S3).

To obtain the minimum age of emplacement of layer $\mathrm{A}$, we performed ${ }^{137} \mathrm{Cs}$ and ${ }^{210} \mathrm{~Pb}$ analyses of the upper $30 \mathrm{~cm}$ of freshwater peat in core TA-03 in Transect 2, where the sand spans 19-24 cm depth (Figure $2 \mathrm{~d}$ and Table S3). Dual peaks in the ${ }^{137} \mathrm{Cs}$ profile may represent downcore migration. We interpret the peak activity at $3 \mathrm{~cm}$ as representing the global maximum atmospheric ${ }^{137} \mathrm{Cs}$ deposition circa A.D. 1963. Disappearance of excess (unsupported) ${ }^{210} \mathrm{~Pb}$ at about $14 \mathrm{~cm}$ depth corresponds to circa A.D. 1900 [Jeter, 2000], and so underlying layer $\mathrm{A}$ was deposited before this time. The maximum age of sand layer $\mathrm{A}$ is given by the $\mathrm{AMS}{ }^{14} \mathrm{C}$ ages of a rooted stem and seeds beneath the sand at $26 \mathrm{~cm}$, which encompass the radiocarbon calibration plateau at circa $520-300 \mathrm{cal}$ yr B.P. (A.D. $1430-1640)$. Together the constraints provided by the ${ }^{137} \mathrm{Cs}$ peak, ${ }^{210} \mathrm{~Pb}$ values, and bounding ${ }^{14} \mathrm{C}$ ages are consistent with a late fifteenth-nineteenth century age for the sand layer.

We identified five additional continuous sand layers similar to layer A (B-F) along Transect 2 (Figures 2c, S1, and S3). The sand layers are $2 \mathrm{~mm}$ to $20 \mathrm{~cm}$ thick and are bound by freshwater peat. They extend at least $1.5 \mathrm{~km}$ inland, with the exception of layer B (>900 m inland). A prominent dark gray tephra enables stratigraphic correlation among Transect 2 cores. Sands B-F are similar in sorting, thickness, and continuity to layer A, and they exhibit the same lithology as beach sand. Several of the sand layers thin landward, although Transect 2 reaches the inland extent of only layer B. We infer sands B-F are tsunami deposits, but more detailed mapping and analysis will be required to confirm this interpretation. Limiting ages on sand layer deposition are obtained from $\mathrm{AMS}^{14} \mathrm{C}$ ages on detrital macrofossils in peat. Layer $\mathrm{B}$ was deposited after $\sim 1.2 \mathrm{ka}$, layer $\mathrm{C}$ after $\sim 1.8 \mathrm{ka}$, and layers D and E after $\sim 2.2 \mathrm{ka}$. Layer F was deposited prior to $\sim 2.2 \mathrm{ka}$ (Figures $2 \mathrm{c}$ and S1).

\section{Discussion}

Tidal stratigraphy beneath the marsh fringing the southern Sitkinak Lagoon records a complex sequence of deposition that was strongly influenced by vertical land-level changes. We infer that abrupt silt-peat contacts record uplift just prior to 290-0, 520-300, and 1050-790 cal yr B.P., and subsidence in A.D. 1964, and after 640-510 cal yr B.P. A sand sheet and abrupt uplift dating to the late fifteenth-nineteenth centuries most likely represent coseismic uplift and tsunami inundation during the largest historical earthquake in the region prior to A.D. 1964, in A.D. 1788. These observations allow us to draw several inferences about the rupture behavior of the megathrust beneath Sitkinak.

A megathrust rupture on 21 July A.D. 1788 near Sitkinak Island caused a 3-10 m tsunami that forced relocation of the first Russian settlement at Three Saints Bay on southwestern Kodiak Island [Soloviev, 1990; Lander, 1996] (Figure 1b). The late fifteenth-nineteenth century age estimate of sand layer A overlaps the age of a horizon uplifted prior to 290-0 cal yr B.P. (Figures 2, S1, and S3). Taken together, evidence for sudden uplift and marine inundation within these time constraints is consistent with coseismic uplift and tsunami inundation in A.D. 1788. Identification of the July A.D. 1788 rupture on Sitkinak Island provides independent evidence for historical reports of a paleoearthquake that spanned $>450 \mathrm{~km}$ of the Alaska-Aleutian megathrust 


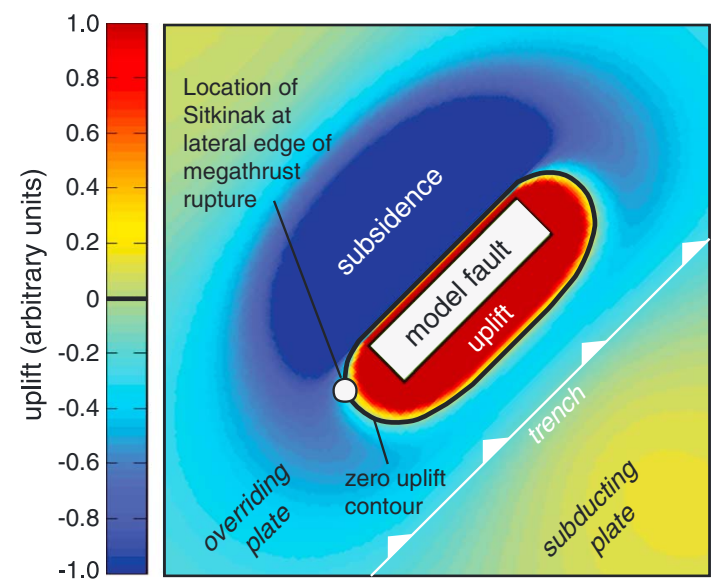

Figure 4. Surface deformation predicted from uniform slip on a rectangular buried thrust fault dipping at $30^{\circ}$. This highly simplified rupture model illustrates how subsidence would have wrapped around the lateral (along-strike) edges of the zone of surface uplift above and near the slip patch during the A.D. 1964 earthquake. from Three Saints Bay to near the Shumagin Islands [Lander, 1996]. A second rupture on 6 August A.D. 1788 (Figure 1b) may have caused a $>30 \mathrm{~m}$ tsunami to inundate Unga and Sanak Islands, 400-575 km west of Sitkinak [Lander, 1996], but at present it is unclear if there were two ruptures or only a single event in A.D. 1788.

We do not observe clear land-level change or tsunami inundation on Sitkinak Island about the time of the A.D. $1938 M_{w} 8.2$ rupture (Figures 1 and 3), in agreement with the lack of historical reports of significant land-level change or tsunami inundation along local and distant coastlines in A.D. 1938 [Lander, 1996]. This implies that slip in the A.D. 1938 rupture was relatively small and far removed from Sitkinak Island as previously suggested by the model of Johnson and Satake [1994] that places a maximum of $3.3 \mathrm{~m}$ coseismic slip on a fault patch centered approximately $140 \mathrm{~km}$ southwest of the island.

Subsidence of the southern coast of Sitkinak Island in A.D. 1964 illustrates how coseismic surface uplift changes abruptly to subsidence at the lateral ends of megathrust ruptures. The apparent inconsistency between $0.45 \pm 0.3 \mathrm{~m}$ coseismic uplift reported on the northern coast in A.D. 1964, and our observation of subsidence $\sim 9 \mathrm{~km}$ to the southwest is explained by the arrest of rupture at or near the island. This phenomenon matches predictions from elastic dislocation models of buried dipping faults, where subsidence troughs wrap around the primary zone of uplift (Figure 4). Similar abrupt transitions from decimeter-scale elastic uplift to subsidence over a few kilometers have been observed during recent megathrust ruptures at Simeulue Island, Indonesia in A.D. 2004; Nias, Indonesia in A.D. 2005; and Tetepare, Solomon Islands in A.D. 2007 [Briggs et al., 2006; Taylor et al., 2008].

The coseismic uplift and subsidence that we infer from Sitkinak Island stratigraphy and microfossils is consistent with the position of the island at the western boundary of the A.D. 1964 rupture and above the A.D. 1788 rupture patch. We propose a simple model whereby Sitkinak Island subsidence events correspond to A.D. 1964-type ruptures, with slip terminating near the island and small or absent tsunami inundation (as recorded in A.D. 1964) [Plafker and Kachadoorian, 1966]. By contrast, uplift occurs during ruptures that extend beneath and beyond Sitkinak and can be accompanied by tsunamis along the island's southern coast; these may be A.D. 1788-type ruptures or ruptures with differing length and widths from those in A.D. 1788 and A.D. 1964. The variable uplift-subsidence history illustrates how islands located above megathrust locked patches can record either uplift or subsidence depending on where ruptures stop along strike; as a consequence, the paleoseismic record at individual sites at other subduction zones should not be assumed to record exclusively coseismic uplift or subsidence.

The coastal record of vertical deformation on Sitkinak Island compares favorably to the paleoseismic record from tidal stratigraphy on nearby Kodiak Island [Carver and Plafker, 2008]. A rupture at $~ 500$ years ago [Gilpin, 1995] observed at several Kodiak Island sites may correspond to uplift and a tsunami preserved in the Sitkinak Lagoon with an age estimate of 520-300 cal yr B.P. Uplift of Sitkinak Island before 1050-790 cal yr B.P. overlaps with the penultimate rupture identified along the A.D. 1964 rupture zone at 900-840 cal yr B.P. [Shennan et al., 2014], but present uncertainties are too large to confidently correlate these ruptures.

Because the A.D. 1788 rupture extended from hundreds of kilometers southwest of Sitkinak Island well into the A.D. 1964 rupture area (Figure 1b), the island does not appear to overlie a section of the megathrust that acts as a persistent barrier to great ruptures. The mixed record of subsidence and uplift prior to A.D. 1788 records ruptures that extended beneath Sitkinak Island or stopped nearby, adding additional support to this idea. Furthermore, it appears that the A.D. 1938 rupture contributed little to moment release adjacent to the A.D. 1964 western rupture edge. Occasional resistance to seismic rupture beneath Sitkinak Island may reflect 
unrecognized structural, rheological, or dynamic controls [Collot et al., 2004; Wang and Bilek, 2014; Noda and Lapusta, 2013] or may only be the apparent outcome of a short sequence drawn from a random process [Kagan et al., 2012]. On the basis of historical records and the paleoseismic history inferred here from land-level changes, we recommend that the assumption of a fixed megathrust rupture boundary near Sitkinak Island be relaxed for the purposes of seismic hazard analysis.

\section{Acknowledgments}

Those who made this research possible through their advice, analyses, access, or logistical help include Rolan Ruoss (Sea Hawk Air, Kodiak City); Gary and Deborah Carver (Kodiak City); U.S. Fish and Wildlife Service (Kodiak City); George Plafker (USGS retired, Menlo Park); David Anderson (U.S. Coast Guard, 1964-65); U.S. Coast Guard (Kodiak City, 2011); Bob Mudd (Sitkinak Island); Ann Morey and Jason Wiest (Oregon State University); Bill Barnhart (USGS, Golden elastic modeling); Stephanie Ross, Holly Ryan, and Steve Kirby (USGS, Menlo Park); and Leslie Hayden, Rob Witter, and Kristi Wallace (USGS, Menlo Park and Anchorage, pumice analysis), funded by the U.S. Geological Survey (USGS) Earthquake Hazards Program and the Multihazards Demonstration Project. Data used to generate the figures are available in the supporting information. We thank Rob Witter (USGS), Kelin Wang, and one anonymous reviewe for their comments that substantially improved the manuscript. Any use of trade, product, or firm names is for descriptive purposes only and does not imply endorsement by the U.S. Government.

The Editor thanks Kelin Wang and an anonymous reviewer for their assistance in evaluating this paper.

\section{References}

Argus, D. F., R. G. Gordon, M. B. Heflin, C. Ma, R. J. Eanes, P. Willis, W. R. Peltier, and S. E. Owen (2010), The angular velocities of the plates and the velocity of Earth's centre from space geodesy, Geophys. J. Int., 180(3), 913-960.

Atwater, B. F. (1987), Evidence for great Holocene earthquakes along the outer coast of Washington State, Science, 236(4804), 942-944.

Briggs, R. W., et al. (2006), Deformation and slip along the sunda megathrust in the great 2005 Nias-Simeulue earthquake, Science, 311(5769), 1897-1901.

Britt, R. H. (1965), Earthquake damage repair at Sitkinak Loran Station, The Engineer's Digest (U.S. Coast Guard), 133, 35-37, October-November-December.

Carver, G., and G. Plafker (2008), Paleoseismicity and neotectonics of the aleutian subduction zone-An overview, in Active Tectonics and Seismic Potential of Alaska, Geophys. Monogr. Ser., vol. 179, edited by J. T. Freymueller et al., pp. 43-63, AGU, Washington, D. C.

Collot, J.-Y., B. Marcaillou, F. Sage, F. Michaud, W. Agudelo, P. Charvis, D. Graindorge, M.-A. Gutscher, and G. Spence (2004), Are rupture zone limits of great subduction earthquakes controlled by upper plate structures? Evidence from multichannel seismic reflection data acquired across the northern Ecuador-southwest Colombia margin, J. Geophys. Res., 109, B11103, doi:10.1029/2004JB003060.

Fierstein, J., and W. Hildreth (1992), The Plinian eruptions of 1912 at Novarupta, Katmai National Park, Alaska, Bull. Volcanol., 54(8), 646-684.

Fournier, T. J., and J. T. Freymueller (2007), Transition from locked to creeping subduction in the Shumagin region, Alaska, Geophys. Res. Lett., 34, L06303, doi:10.1029/2006GL029073.

Freymueller, J. T., H. Woodard, S. C. Cohen, R. Cross, J. Elliot, C. F. Larsen, S. Hreinsdóttir, and C. Zweck (2008), Active deformation processes in Alaska, based on 15 years of GPS measurements, in Active Tectonics and Seismic Potential of Alaska, Geophys. Monogr. Ser., vol. 179, edited by J. T. Freymueller et al., pp. 1-42, AGU, Washington, D. C.

Gilpin, L. M. (1995), Holocene paleoseismicity and coastal tectonics of the Kodiak Islands, Alaska, PhD dissertation, Univ. of California, Santa Cruz, Santa Cruz, Calif.

Hemphill-Haley, E. (1995), Diatom evidence for earthquake-induced subsidence and tsunami $300 \mathrm{yr}$ ago in southern coastal Washington, Geol. Soc. Am. Bull., 107(3), 367-378.

Hutchinson, l., and A. L. Crowell (2007), Recurrence and extent of great earthquakes in Southern Alaska during the late Holocene from an analysis of the radiocarbon record of land-level change and village abandonment, Radiocarbon, 49(3), 1323-1385.

Jeter, H. W. (2000), Determining the ages of recent sediments using measurements of trace radioactivity, Terra Aqua, 78, 21-28.

Johnson, J. M., and K. Satake (1994), Rupture extent of the 1938 Alaskan earthquake as inferred from tsunami waveforms, Geophys. Res. Lett., $21(8), 733-736$.

Kagan, Y. Y., D. D. Jackson, and R. J. Geller (2012), Characteristic earthquake model, 1884-2011, R.I.P, Seismol. Res. Lett., 83(6), 951-953.

Kemp, A. C., S. E. Engelhart, S. J. Culver, A. Nelson, R. W. Briggs, and P. J. Haeussler (2013), Modern salt-marsh and tidal-flat foraminifera from Sitkinak and Simeonof Islands, Southwestern Alaska, J. Foraminiferal Res., 43(1), 88-98.

Lander, J. F. (1996), Tsunamis Affecting Alaska 1737-1996, 195 pp., NOAA/NGDC, Boulder, Colo.

Matthews, K. J., R. D. Müller, P. Wessel, and J. M. Whittaker (2011), The tectonic fabric of the ocean basins, J. Geophys. Res., 116, B12109, doi:10.1029/2011JB008413.

Melnick, D., B. Bookhagen, M. R. Strecker, and H. P. Echtler (2009), Segmentation of megathrust rupture zones from fore-arc deformation patterns over hundreds to millions of years, Arauco peninsula, Chile, J. Geophys. Res., 114, B01407, doi:10.1029/2008JB005788.

Meltzner, A. J., K. Sieh, H.-W. Chiang, C.-C. Shen, B. W. Suwargadi, D. H. Natawidjaja, B. Philibosian, and R. W. Briggs (2012), Persistent termini of 2004- and 2005-like ruptures of the Sunda megathrust, J. Geophys. Res., 117, B04405, doi:10.1029/2011JB008888.

Nelson, A. R., I. Shennan, and A. J. Long (1996), Identifying coseismic subsidence in tidal-wetland stratigraphic sequences at the Cascadia subduction zone of western North America, J. Geophys. Res., 101(B3), 6115-6135.

Noda, H., and N. Lapusta (2013), Stable creeping fault segments can become destructive as a result of dynamic weakening, Nature, 493(7433), 518-521.

Plafker, G. (1969), Tectonics of the March 27, 1964 Alaska earthquake, U.S. Geol. Surv. Prof. Pap., 543-I, 74.

Plafker, G., and R. Kachadoorian (1966), Geologic effects of the March 1964 earthquake and associated seismic sea waves on Kodiak and nearby islands, Alaska, U.S. Geol. Surv. Prof. Pap., 543-D, D1-D46.

Plafker, G., and J. C. Savage (1970), Mechanism of the Chilean earthquakes of May 21 and 22, 1960, Geol. Soc. Am. Bull., $81(4), 1001$.

Ross, S. L., et al. (2013), The SAFRR (Science Application for Risk Reduction) Tsunami scenario-Executive summary and introduction, U.S. Geological Survey Open-File Report, 2013-1170-A, 17 pp.

Ryan, H. F., R. von Huene, R. E. Wells, D. W. Scholl, S. Kirby, and A. E. Draut (2012), History of earthquakes and tsunamis along the eastern AleutianAlaska megathrust, with implications for tsunami hazards in the California Continental Borderland, in Studies by the U.S. Geological Survey in Alaska, 2011, U.S. Geol. Surv. Prof. Pap., 1795-A, edited by J. A. Dumoulin and C. Dusel-Bacon, 31 pp.

Ryan, W. B. F., et al. (2009), Global multi-resolution topography synthesis, Geochem. Geophys. Geosyst., 10, Q03014, doi:10.1029/ $2008 \mathrm{GC} 002332$

Savage, J. C., and L. M. Hastie (1966), Surface deformation associated with dip-slip faulting, J. Geophys. Res., 71(20), 4897-4904.

Shennan, l., N. Barlow, and R. Combellick (2008), Paleoseismological records of multiple great earthquakes in southcentral Alaska: A 4000-year record at Girdwood, in Active Tectonics and Seismic Potential of Alaska, Geophys. Monogr. Ser., vol. 179, edited by J. T. Freymueller et al., pp. 185-199, AGU, Washington, D. C.

Shennan, I., R. Bruhn, and G. Plafker (2009), Multi-segment earthquakes and tsunami potential of the Aleutian megathrust, Quat. Sci. Rev., 28(1-2), 7-13.

Shennan, I., R. Bruhn, N. Barlow, K. Good, and E. Hocking (2014), Late Holocene great earthquakes in the eastern part of the Aleutian megathrust, Quat. Sci. Rev., 84, 86-97.

Soloviev, S. L. (1990), Sanak-Kodiak tsunami of 1788, Sci. Tsunami Hazards, 8(1), 34-38. 
Taylor, F. W., R. W. Briggs, C. Frohlich, A. Brown, M. Hornbach, A. K. Papabatu, A. J. Meltzner, and D. Billy (2008), Rupture across arc segment and plate boundaries in the 1 April 2007 Solomons earthquake, Nat. Geosci., 1(4), 253-257.

von Huene, R., J. J. Miller, and W. Weinrebe (2012), Subducting plate geology in three great earthquake ruptures of the western Alaska margin, Kodiak to Unimak, Geosphere, 8(3), 628-644.

Wang, K., and S. L. Bilek (2014), Invited review paper: Fault creep caused by subduction of rough seafloor relief, Tectonophysics, 610, 1-24.

Wesson, R. L., O. S. Boyd, C. S. Mueller, C. G. Bufe, A. D. Frankel, and M. D. Petersen (2007), Revision of time-independent probabilistic seismic hazard maps for Alaska, U.S. Geol. Surv. Open-File Rep., 2007-1043, 33 pp. 